\title{
The Development of STEM-E based Biology Learning Tools to Train Students' Scientific Literacy and Entrepreneurial Interest
}

\author{
Fadhil Ardhiansyah ${ }^{1}$, Sri Mulyani. E.S², Siti Alimah ${ }^{3}$ \\ $\left\{\underline{\text { fadhilardhi9@gmail.com }}{ }^{1}, \underline{\text { nanik_es@mail.unnes.ac.id }}{ }^{2}\right.$, siti_alimah@mail.unnes.ac.id $\left.^{3}\right\}$
}

Graduate School, Universitas Negeri Semarang, Indonesia ${ }^{123}$

\begin{abstract}
At this time, biology learning is directed to 21 st century competence by training scientific literacy and entrepreneurial interest. This study aims to test the validity and effectiveness of STEM-E based biology learning tools, particularly in learning digestion system material, in order to train students' scientific literacy and entrepreneurial interests. The research method used ADDIE model. The results of the study showed: (1) the developed learning tools obtained a very valid with an average value of 97 and (2) the effectiveness of the learning tools in training students' scientific literacy and entrepreneurial interests was high in catagory with an average value of 0.71 and 0.76 and the hypothesis test obtained the results of sig. $0.000<\alpha=0.05$. Based on these findings, the STEM-E-based biology learning tools in digestive system material meets the criteria of validity and effectiveness to train students' scientific literacy and entrepreneurial interests.
\end{abstract}

Key words: STEM-E Learning Tools, Scientific Literacy, Entrepreneurial Interest.

\section{Introduction}

An ideal biology learning focuses on the study of phenomena in the biological context as a whole, involving the role of technology and its application in order to produce innovative products that can be utilized by the wider community [1][2]. The facts that occur in biology learning emphasize students to fulfill knowledge of subject matter [3][4]. This can be seen from the teacher's emphasis on learning which directs the students to solve knowledge problems. This fact makes biology learning not in accordance with its nature and it does not ideally train students to develop three domains that are attitudes, knowledge, and skills.

Another fact found in biology learning is the lack of students in mastering scientific literacy [5][6]. Based on the latest data, Indonesian students were ranked 62nd out of 70 countries [7]. From this data, more attention is given to the government, educational institutions, and education experts to improve the quality of biology learning as a science discipline to train scientific literacy [8][9].

In addition, the current biology learning is expected to lead the formation of 21 st century learning and to prepare graduates who are able to compete in the working world [10]. The learning form requires students to develop scientific literacy and graduates who are able to form independent entrepreneurship and to utilize the concepts of biological science knowledge in order to produce superior products. 
Answering the challenges of biology learning nowadays, one way that can be done is by developing biology learning tools based on Science, Technology, Engineering, Mathematics and Entrepreneurship (STEM-E) in food digestive systems material.

Learning biology towards the 21 st century emphasizes students developing scientific literacy can be explored in depth in food digestive system material, such as in assessing the role of food substances and possible health effects when there are advantages and disadvantages and focusing on problems such as digestive system disorders that are often felt and found in everyday life that is packaged through the aspects of Science and its application forms with Technology, Engineering, and Mathematics.

This is supported by previous researches [6][11][12], regarding the development of STEM-based PjBL learning that can improve scientific literacy. [13] developed STEM-based Student Worksheets that can have an effect on improving scientific literacy.

Therefore, it is necessary to conduct a study entitled "The Development of STEM-E based Biology Learning Tools to Train Students' Scientific Literacy and Entrepreneurial Interest" in order to prepare 21 st century learning and graduates who are able to compete in the working world.

\section{Method}

The development model in this study is ADDIE [14], namely Analysis (needs analysis and performance analysis), Design (designing the learning tools according to the goals), Develop (drafting the learning tools according to the 2013 curriculum, carrying out the validation of learning tools to experts, and carrying out the limited scale trials in two schools that are SMA Negeri 2 Pati and SMA Negeri 1 Randudongkal, Pemalang Regency), Implementation (implementing the learning tools that had been made and tested on a limited scale then tested on a wide scale in SMA 1 Margasari Regency Tegal in class XI IPA 3 that was chosen by Purposive Sampling, Evaluation (carrying out an assessment with a reasoned multiple-choice test instrument to measure scientific literacy and non-test in the form of questionnaire sheets to measure entrepreneurial interest). The data analysis in this research employed N-Gain test and hypothesis test using paired sample t-test.

\section{Results and Discussion}

\subsection{The Validity of Learning Tools}

The products produced from the development of learning tools were syllabus, lesson plans, teaching materials, worksheets, scientific literacy tests and entrepreneurial interest questionnaires in food digestive system material. Components assessed from the learning tools validity consist of three parts that were feasibility of content, presentation and language.

Furthermore, the validity evaluation results of the learning tools from the experts, the learning materials, and the learning evaluation are presented in Table 1. 
Table 1. The Validity Results of Learning Tools

\begin{tabular}{clll}
\hline No. & Product & Value & Category \\
\hline 1. & Syllabus & 100 & Very Valid \\
2. & Lesson plan & 100 & Very Valid \\
3. & Teaching materials & 91 & Very Valid \\
4. & Student worksheet & 100 & Very Valid \\
5. & Test of Scientific Literacy & 98 & Very Valid \\
6. & Questionnaire of Entrepreneurial Interest & 98 & Very Valid \\
Average Value and Category & 97 & Very Valid \\
\hline
\end{tabular}

Based on the Table 1, the internal validity results of the learning tools were very valid with an average value of 97 . These results showed that the expert validators gave an appreciation for the product of the developed learning tools.

After carrying out internal validity, it was continued by external validity test in a limited scale focusing on scientific literacy tests. Using analysis from the Anates Version 4.0 program, the obtained results showed that the test was valid because $r_{\text {count }}>r_{\text {table }}$ with a very significant category.

Factors affecting the learning tools validity become very valid in general, and it is caused by making adjustments: (1) indicators set on the instrument of validity, (2) criteria for internal validity, with material content and theory according to the objectives formulation basis and constructively paying attention to the relationship between one component and another component which is arranged systematically, and (3) testing criteria externally by paying attention to the students' level of cognitive development.

The statement is supported by the results [15][16], to obtain good validity results, the learning tools must adjust the criteria on the item of validator assessment and pay attention to the complexity of the development goals, namely students with the appropriate level of thinking.

While the specific factors, the making of learning tools meets the criteria in training scientific literacy as stated [3][8][15][17], including: (1) there are scientific concepts applied to daily life and (2) the process of scientific inquiry in each step of learning.

For self-interest forms of entrepreneurship, the learning tools were made to adjust the local potential of the school is in processing coconut products. The advantage of this local potential gives a positive value to the validity of the learning tools [18].

\subsection{Effectiveness of Learning Tools to Train Students' Scientific Literacy and Entrepreneurial Interest}

The effectiveness of learning tools can be measured by how much the average score increases in scientific literacy and entrepreneurial interest before and after treatment using the STEM-E-based biology learning tools in digestive system material through the N-gain test presented in Table 2 and Table 3.

Table 2. Result of Scientific Literacy

\begin{tabular}{lll}
\hline & Before & After \\
\hline Average Value & 41 & 83 \\
$N$-gain & 0.71 & \\
Category & High & \\
\hline
\end{tabular}


Table 3. Result of Entrepreneurial Interest

\begin{tabular}{lll}
\hline & Before & After \\
\hline Average Value & 40 & 86 \\
$N$-gain & 0.76 & \\
Category & High & \\
\hline
\end{tabular}

The hypothesis was tested using paired sample t-test with the results of sig. $0.000<\alpha=$ 0.05 , it indicated that there were significant differences between the average value of scientific literacy and entrepreneurial interest before and after treatment using the STEM-E-based learning tools. Based on these findings, it means that the developed learning tools are very effective in terms of training students' science literacy and entrepreneurial interests.

Scientific literacy value can increase high because in making learning tools, it connects concepts in daily life through the integration of STEM-E aspects with concepts learned in food digestive system material. This is in line with the opinion [6][15][19][20], that students' scientific literacy will increase if the learning is able to apply scientific concepts in the surrounding environment with the existing learning materials.

Another thing is also because in making STEM-E teaching materials and worksheets, it makes the students search and read scientific phenomena that are applied to the real activities by creating innovation project in food digestive system material. With the habit of reading and searching for science articles contained in teaching materials, students can practice concepts and facts of science [8][15][21]. This concept also affects the speed and the effectiveness of students in doing the exercise of scientific literacy. Other forms such as project implementation on worksheets, make students more motivated, active, and confident [13]. This activity not only affects the students' learning outcomes but also increase their scientific literacy.

In addition, the making of STEM-E-based evaluation instruments has met the criteria set by [7] to train scientific literacy such as (1) the questions do not only require the achievement of Basic Competencies but they also contain broad concepts, (2) it contains information or data in the form of data presentation to be processed, (3) type of questions must be combination (multiple choice and essay) that has been modified into reasoned multiple choice, and (4) it includes application content, namely in making learning products.

Furthermore, the score of students' entrepreneurial interest can increase high because the STEM-E learning tools are made to train students to independently make each product in the form of Nata and virgin coconut oil (VCO) innovations. By making this product, the independent innovation has a contribution on fostering students' interest in conducting entrepreneurial activities as well as other positive forms of learning experiences that become a positive provision when graduating [18][22].

\section{Conclusion}

The development of STEM-E-based biology learning tools in food digestive system material meets the criteria of validity and effectiveness to train students' scientific literacy and entrepreneurial interests. 
Acknowledments. The author expresses her gratitude the Hibah Penelitian Tesis Pascasarjana Universitas Negeri Semarang for providing research funding. 


\section{Reference}

[1] Aulia, E.V, Poedjiastoeti, S and Agustini, R. :The Effectiveness of Guided Inquiry-based Learning Material on Students' Science Literacy Skills. Journal of physic. Vol. 94, pp. 1-7 (2018).

[2] Pitts, W and Quam, A.L. :Engaging the Framework for Information Literacy for Higher Education as a Lens for Assesment in an ePortofolio Social Pedagogy Ecosystem for Science Teacher Education. International Journal of ePortofolio. Vol. 9, pp. 29-44 (2019).

[3] Yuliyanti, T.E and Rusilowati, A. :Analisis Buku Ajar Fisika SMA Kelas XI Berdasarkan Muatan Literasi Sains di Kabupaten Tegal. Unnes Physic Education Journal. Vol. 3, pp. 69-72 (2014).

[4] Rakhmawati, S, Muspiroh, N and Azmi, N. :Analisis Pelaksanaan Kurikulum 2013 ditinjau dari Standar Proses dan dalam Pembelajaran Biologi Kelas X di SMA Negeri 1 Karangkeng. Jurnal Sains dan Pendidikan Sains. Vol. 5, pp. 156-164 (2016).

[5] Diana, S, Rachmatulloh, A and Rakhmawati, E.U. :Profil Kemampuan Literasi Sains Siswa SMA berdasarkan Instrumen Scientific Literacy Assesment (SLA). Prosiding Seminar Nasional XII Pendidikan Biologi FKIP UNS 2015. pp. 285-291 (2015).

[6] Afriana, J, Permanasari, A and Fitriani, A. :Project Based Learning Integrated to STEM to Enhance Elementary School's Students Scientific Literacy. Jurnal Pendidikan IPA Indonesia. Vol. 5, pp. 261-267 (2016).

[7] OECD. PISA 2015 Result: Executive Summary. 2016.

[8] Budiningsih, T.Y, Rusilowati, A and Marwoto, P. :Pengembangan Buku Ajar IPA Terpadu Berorientasi Literasi Sains Materi Energi dan Suhu. Journal of Innovative Science Education. Vol. 4, pp. 34-40 (2015).

[9] Rustaman, N.Y. :Mewujudkan Sistem Pembelajaran Sains/Biologi Berorientasi Pengembangan Literasi Peserta Didik. Prosiding Seminar Nasional III Tahun 2017 "Biologi, Pembelajaran dan Lingkungan Hidup Perspektif Interdisiplinier”. pp. 1-8 (2016).

[10] Corebima, D. :Pembelajaran Biologi di Indonesia Bukan Untuk Hidup. Proceeding Biology Education Conference. pp. 8-22 (2016).

[11] Khaeroningtyas, N, Permanasari, A and Hamidah, I. :STEM Learning In Material of Temperature and Its Change to Improve Science Literacy of Junior High School. Jurnal Pendidikan IPA Indonesia. Vol. 5, pp. 94-100 (2016).

[12]Lutfi, Ismail and Azis, A.A. :Pengaruh Project Based Learning terintegrasi STEM Terhadap Literasi Sains, Kreativitas dan Hasil Belajar Peserta Didik. Prosiding Seminar Nasional Biologi dan Pembelajaran. pp. 189-194 (2018).

[13] Sulistiyowati, Abdurrahman and Jalmo, T. :The Effect of STEM-Based Worksheet on Students's Science Literacy. Jurnal Keguruan dan Ilmu Tarbiyah. Vol. 3, pp. 89-96 (2018).

[14] Aldoobie, N. :ADDIE Model. American International Journal of Contemporary Research. Vol. 5, pp. 68-72 (2015).

[15] Dewi, F.I. :Validitas Perangkat Pembelajaran Berbasis Literasi Sains Pada Materi Virus Kelas X SMA. Jurnal BioEdu. Vol. 5, pp. 166-173 (2016).

[16] Wiyanti, W. :Pengembangan Perangkat Pembelajaran Biologi Berbasis Lingkungan dengan Setting Modified Inquiry untuk Meningkatkan Karakter dan Pemahaman Konsep Siswa SMA. Jurnal Ilmiah Pendidikan dan Pembelajaran. Vol. 1, pp. 1-9 (2017).

[17] Fakhriyah, F, Masfuah, S, Roysa, M, Rusilowati, A and Rahayu, E.S. :Student's Science Literacy in The Aspect of Content Science. Jurnal Pendidikan IPA Indonesia. Vol. 6, pp. 81-87 (2017).

[18] Sumarti, S.S, Aris, S.R.S and Aini, R.N. :Chemoentrepreneurship With Cooperative Integrated Process Inquiry Strategy to Increase Entrepreneurial Interest and Learning Motivation. Jurnal Pendidikan IPA Indonesia. Vol. 7, pp. 172-180 (2018). 
[19] Pertiwi, D.U, Atanti, R.D and Ismawati, R. :Pentingnya Literasi Sains Pada Pembelajaran IPA SMP Abad 21. Indonesian Journal of Natural Science Education. Vol. 1, pp. $24-29$ (2017).

[20] Lestari, P, Sarwi and Sumarti, S.S. :STEM-Based Project Learning Model to Increase Science Process and Creative Thinking Skills of 5th Grade. Journal of Primary Education. Vol. 7, pp. 18-24 (2018).

[21] Anggraini. :Analisis Kemampuan Literasi Sains Siswa SMA Kelas X di Kota Solok. Proceeding Mathematics and Sciences Forum 2014, pp. 161-170 (2014).

[22] Sunarya, R.A, Supartono and Sumarti, S.S. :Analisis Hasil Belajar dan Minat Wirausaha Siswa Menggunakan Bahan Ajar Berorientasi Chemoentrepreneurship. Jurnal Inovasi Pendidikan IPA. Vol. 12, pp. 2065-2074 (2018). 